\title{
Extracellular Adenosine Triphosphate Activates Calcium Mobilization in Human Phagocytic Leukocytes and Neutrophil/Monocyte Progenitor Cells
}

\author{
Daniel S. Cowen," Hillard M. Lazarus,"5 Susan B. Shurin," Sara E. Stoll," and George R. Dubyak ${ }^{\text {st }}$ \\ Departments of Physiology and Biophysics, ${ }^{\prime}$ Pharmacology, ${ }^{*}$ Medicine, ${ }^{\ddagger}$ and Pediatrics" and the Ireland Cancer Center, ${ }^{\S}$ \\ Case Western Reserve University School of Medicine, Cleveland, Ohio 44106
}

\begin{abstract}
We have examined the ability of extracellular ATP to elicit intracellular $\mathrm{Ca}^{2+}$ mobilization in a broad range of human leukocytes at particular stages of hematopoietic differentiation. The average cytosolic $\left[\mathrm{Ca}^{2+}\right]$ in various leukocyte populations was measured in Fura 2-loaded cell suspensions while the cytosolic $\left[\mathrm{Ca}^{2+}\right]$ in individual, Indo 1-loaded leukocytes was assayed by flow cytometric methods. Utilizing normal blood- and marrow-derived cells, human leukemic cell lines, and mononuclear cell fractions derived from the blood of patients with various leukemias, we have found that $\mathrm{ATP}$-induced $\mathrm{Ca}^{2+}$ mobilization appears restricted to leukocytes of neutrophil/monocyte ontogeny. Significant ATP-induced increases in cytosolic $\left[\mathrm{Ca}^{2+}\right]$ were observed in neutrophils, monocytes, and myeloid progenitor cells as immature as myeloblasts, but not in lymphocytes. Extensive characterization of the ATP-induced changes in $\left[\mathrm{Ca}^{2+}\right]$ observed in the $\mathrm{HL}-60$ promyelocytic cell line have indicated these $\mathrm{Ca}^{2+}$-mobilizing effects of ATP can be correlated with an activation of inositol phospholipid breakdown via the occupation of $P_{2}$-purinergic receptors. Significantly, of the various agonists (FMLP, platelet-activating factor, $\mathbf{L T B}_{4}$, and ATP) which elicit equivalent and maximal $\mathrm{Ca}^{2+}$ mobilization in mature neutrophils and monocytes, ATP was the most efficacious stimulant of $\mathrm{Ca}^{2+}$ mobilization in immature neutrophil/monocyte precursors. Thus, expression of putative $\mathbf{P}_{2}$-purinergic receptors for ATP appears to precede expression of other receptor types known to activate the inositol phospholipid signaling cascades in terminally differentiated phagocytes.
\end{abstract}

\section{Introduction}

Extracellular ATP, at micromolar/nanomolar concentrations, has been shown to induce significant functional changes in a wide variety of normal and transformed cell types (reviewed in reference 1). In most cases, these actions of ATP can be functionally distinguished from those elicited in response to occupation of the well-characterized $A_{1}$ and $A_{2}$ adenosine receptors. Thus, a growing body of data suggests the existence of specific cell surface receptors, termed $P_{2}$-purinergic, for extracellular ATP. Whereas ATP is present in millimolar concen-

\section{Address reprint requests to Dr. Dubyak. \\ Received for publication 26 July 1988 and in revised form $18 \mathrm{No}$ - vember 1988.}

\section{J. Clin. Invest.}

(c) The American Society for Clinical Investigation, Inc.

$0021-9738 / 89 / 05 / 1651 / 10 \$ 2.00$

Volume 83, May 1989, 1651-1660 trations in the cytosol of all eukaryotic cell types, extracellular levels of the nucleotide are normally maintained at extremely low levels by ubiquitous ecto-ATPases and ectophosphatases which rapidly and efficiently hydrolyze extracellular nucleotides (2). However, ATP can be copackaged in both adrenergic and cholinergic neurotransmitter granules and thus be released during neurotransmission into synaptic spaces $(3,4)$. Moreover, cytosolic ATP stores can be released by sudden breakage of intact cells as might occur during rupture of blood vessels and other tissue injury. Finally, ATP, which is also copackaged with serotonin in platelet granules, can be locally released in significant amounts during platelet activation (5). These latter two sources suggest that significant amounts of extracellular ATP may locally accumulate at vascular sites of thrombus formation and infection/inflammation. If so, the possibility may be considered that extracellular ATP can modify the function of the phagocytic cell types (neutrophils and monocytes) present at such inflammatory sites.

In several cell types (6-11), extracellular ATP has been shown to induce rapid activation of the inositol phospholipid/ protein kinase $\mathrm{C}$ signaling cascade and thus produce significant changes in cytosolic $\left[\mathrm{Ca}^{2+}\right],\left[\mathrm{H}^{+}\right]$, and inositol phosphate/diacylglycerol levels. In phagocytic cells, activation of this inositol phospholipid/protein kinase $\mathrm{C}$ signaling pathway is among the earliest events triggered by inflammatory stimuli (12-14) and this activation is believed to play a role in triggering or modulating chemotaxis, secretion, phagocytosis, and superoxide release (15-17).

We have previously demonstrated that extracellular ATP, acting through $\mathrm{P}_{2}$-purinergic receptors, can activate this inositol phospholipid/protein kinase $\mathrm{C}$ signaling cascade in the HL-60 human promyelocytic leukemia cell line $(18,19)$. Significantly, this ATP-induced activation of inositol phospholipid breakdown and subsequent $\mathrm{Ca}^{2+}$ mobilization was observed in both undifferentiated HL-60 cells and in HL-60 cells differentiated along the neutrophil pathway. In addition, Ward et al. (20) and Kuhns et al. (21) have recently demonstrated that extracellular ATP triggers large, but transient, increases in cytosolic $\left[\mathrm{Ca}^{2+}\right]$ in human neutrophils. The ability of extracellular ATP to elicit significant changes in cytosolic $\left[\mathrm{Ca}^{2+}\right]$ in circulating neutrophils and in HL-60 promyelocytic leukemia cells suggests that the expression of $\mathrm{P}_{2}$-purinergic receptors may be a common feature of both differentiated phagocytic leukocytes and the neutrophil/monocyte progenitor cells normally found in bone marrow. To test this possibility we have characterized the effects of extracellular ATP on cytosolic $\left[\mathrm{Ca}^{2+}\right]$ in a broad range of blood- and marrow-derived human leukocytes and human leukocyte progenitor cells. The use of leukemic cells (both established human cell lines and blood cells isolated from patients with various types of leukemia) facilitated the examination of large numbers of particular progenitor-type cells at specific stages of differentiation. 


\section{Methods}

Cell culture. HL-60 cells, U937 cells, KG-1 cells, KG-1A cells, K562 cells, Hut-78 cells, and Molt-4 cells obtained from the American Type Tissue Culture Collection (Rockville, MD) were routinely maintained between $3 \times 10^{5}$ and $1 \times 10^{6}$ cells $/ \mathrm{ml}$ in Iscove's medium (Gibco Laboratories, Grand Island, NY) supplemented with $25 \mathrm{mM}$ Hepes, $5 \%$ fetal bovine serum (Hyclone Laboratories, Logan, UT), and 5\% calf bovine serum (Hyclone Laboratories). Where specified in the text, HL-60 cells were differentiated into neutrophil-type cells by treatment for $48 \mathrm{~h}$ with $500 \mu \mathrm{M}$ dibutyryl cyclic AMP (22).

Cell isolation. Blood mononuclear cells were isolated from heparinized venous blood drawn from healthy volunteers, by centrifugation at $400 \mathrm{~g}$ through $1.077 \mathrm{~g} / \mathrm{ml}$ density Ficoll/Hypaque (Sigma Chemical Co., St. Louis, MO) (23). Monocytes were isolated by adherence. Blood mononuclear cells were incubated at $1 \times 10^{7}$ cells $/ \mathrm{ml}$ in Iscoves's medium supplemented with $25 \mathrm{mM}$ Hepes and $10 \%$ heat-inactivated fetal bovine serum for $30 \mathrm{~min}$ at $37^{\circ} \mathrm{C}$ in albumin-coated plastic petri dishes. These dishes had been incubated the previous night at $4^{\circ} \mathrm{C}$ with $3.5 \%$ bovine serum albumin, and were washed four times with phosphate-buffered saline before incubation of mononuclear blood cells Nonadherent cells were removed by washing the dish with a basal salt solution free of $\mathrm{Ca}^{2+}$ and $\mathrm{Mg}^{2+}$, and were used for studies of lymphocytes. Adherent monocytes were removed by shaking, after incubation at $37^{\circ} \mathrm{C}$ for $5 \mathrm{~min}$ with Hanks' balanced salt solution containing 0.5 $\mathrm{g} /$ liter trypsin and $0.2 \mathrm{~g} /$ liter EDTA. Neutrophils were isolated from blood after Ficoll centrifugation and three cycles of hypotonic lysis (24). Bone marrow mononuclear cells were isolated by Ficoll centrifugation of bone marrow obtained from healthy donors or from nonleukemic patients undergoing autologous bone marrow transplantation. Mononuclear leukemic cells were isolated by Ficoll centrifugation of heparinized venous blood drawn from patients diagnosed with the specified types of leukemias. When necessary, erythrocytes were removed from mononuclear cell fractions by a single cycle of hypotonic lysis for $30 \mathrm{~s}$ with $0.2 \% \mathrm{NaCl}$. Myeloid leukemias were classified according to the French-American-British (FAB) ${ }^{1}$ classifications (25).

Fura-2 cytosolic $\left[\mathrm{Ca}^{2+}\right]$ measurements. After washing two times with a basal salt solution containing $125 \mathrm{mM} \mathrm{NaCl}, 5 \mathrm{mM} \mathrm{KCl}, 1 \mathrm{mM}$ $\mathrm{MgCl}_{2}, 1.5 \mathrm{mM} \mathrm{CaCl}_{2}, 25 \mathrm{mM}$ Hepes (ph 7.4), $5 \mathrm{mM}$ glucose, and 2 $\mathrm{mg} / \mathrm{ml}$ bovine serum albumin (ICN Immunobiologicals, Lisle, IN) cytosolic $\left[\mathrm{Ca}^{2+}\right]$ was measured in isolated cells or cell lines using the fluorescent dye Fura 2 following previous methods (10). Routinely, washed cell suspensions contained 1-2 $\times 10^{6}$ cells $/ \mathrm{ml}$; such suspensions were incubated with $1 \mu \mathrm{M}$ of the acetomethoxy ester of Fura-2 (Molecular Probes, Eugene, OR) for $30 \mathrm{~min}$ at $37^{\circ} \mathrm{C}$; the cells were then pelleted, washed, and incubated an additional $10 \mathrm{~min}$ at $37^{\circ} \mathrm{C}$. After washing/resuspension in fresh medium, the Fura 2-loaded cell suspensions were stored on ice. $\mathrm{Ca}^{2+}$ measurements were made at $37^{\circ} \mathrm{C}$ with continual stirring. Nucleotides and the chemotactic peptide formylmethionylleucylphenylalanine (FMLP) were obtained from Sigma Chemical Co.; ATP $\mathrm{S}$ from Boehringer-Mannheim Biochemicals (Indianapolis, IN); platelet-activating factor (PAF) from CalbiochemBehring Corp. (San Diego, CA); leukotriene $\mathrm{B}_{4}\left(\mathrm{LTB}_{4}\right)$ was a generous gift from Dr. Seymour Mong of Smith-Kline Beckman (King of Prussia, PA).

Indo-1 cytosolic $\left[\mathrm{Ca}^{2+}\right]$ measurements. Cells were loaded at $37^{\circ} \mathrm{C}$ for $30 \mathrm{~min}$ at $1 \times 10^{6} \mathrm{cells} / \mathrm{ml}$ with $5 \mu \mathrm{M}$ of the acetomethoxy ester of Indo-1 (Molecular Probes, Eugene, OR) in a basal salt solution containing $1 \mathrm{mg} / \mathrm{ml}$ bovine serum albumin and $5 \mathrm{mM}$ glucose. The cells were pelleted, resuspended in fresh medium, and incubated an additional $10 \mathrm{~min}$. The cells were recentrifuged, resuspended in fresh medium, and stored on ice before measurements. Calcium mobilization was examined at $37^{\circ} \mathrm{C}$ as described by Rabinovitch et al. (26). An Ortho IIS flow cytometer (Ortho Diagnostic Systems Inc., Raritan, NJ)

1. Abbreviations used in this paper: FAB, French-American-British (classification); PAF, platelet-activating factor. and a 2151 Data Acquisition System were used to acquire size and fluorescence measurements correlated with time. The ratio of Indo-1 violet $(405 \mathrm{~nm}) / \mathrm{blue}(460 \mathrm{~nm})$ fluorescence was used as a measure of cytosolic $\left[\mathrm{Ca}^{2+}\right]$. The percentage of cells responsive to ATP or FMLP was calculated by fluorescence ratio histogram subtraction using data acquired before, and during, the 35-60-s interval after stimulation by agonist.

\section{Results}

Effects of extracellular ATP on cytosolic $\left[\mathrm{Ca}^{2+}\right]$ in $\mathrm{HL}-60$ cell line. Fig. $1 A$ illustrates the typical changes in cytosolic $\left[\mathrm{Ca}^{2+}\right]$ observed in Fura 2-loaded, undifferentiated HL60 cells when exposed to $3 \mu \mathrm{M}$ extracellular ATP. In the absence of significant free extracellular $\left[\mathrm{Ca}^{2+}\right]$, ATP induced a very rapid (complete within $5 \mathrm{~s}$ ) increase in cytosolic $\left[\mathrm{Ca}^{2+}\right]$ from the basal level of approximately $100 \mathrm{nM}$ to a peak level exceeding $1 \mu \mathrm{M}$; this increase was followed by a rapid (complete within $60 \mathrm{~s}$ ) decay to the prestimulus level. Conversely, in the presence of $1.5 \mathrm{mM}$ extracellular $\left[\mathrm{Ca}^{2+}\right]$, the rapid, initial increase was followed by a sustained phase of elevated cytosolic $\left[\mathrm{Ca}^{2+}\right]$ which only gradually decreased over the next several minutes. This sustained phase, but not the initial, rapid increase, was completely blocked by inclusion of $20 \mu \mathrm{M} \mathrm{LaCl}$, which inhibits both voltage-sensitive and voltage-insensitive $\mathrm{Ca}^{2+}$ influx pathways, in normal $\mathrm{Ca}^{2+}$-containing medium (data not shown). Conversely, inclusion of specific antagonists (nifedipine, D600) of voltage-sensitive $\mathrm{Ca}^{2+}$ channels (data not shown) had no effect on the ATP-induced signals. HL-60 cells appear to be unusually sensitive to extracellular [ATP] in that the threshold concentration varies between 3 and $10 \mathrm{nM}$ (Fig. $1 \mathrm{~B})$. Five- to sevenfold increases in peak $\left[\mathrm{Ca}^{2+}\right]$ were invariably triggered by $50-100 \mathrm{nM}$ ATP; [ATP] $>1 \mu \mathrm{M}$ produced maximal effects.

The selectivity of the ATP effects on $\mathrm{Ca}^{2+}$ mobilization in HL-60 cells was also examined; these results are summarized in Table I. ATP was the most potent of all tested adenine nucleotides/nucleosides; the $\mathrm{EC}_{50}$ for ADP action was $10 \mu \mathrm{M}$ while AMP and adenosine produced no significant $\mathrm{Ca}^{2+}$ mobilization at concentrations up to $300 \mu \mathrm{M}$. Modification of the triphosphate moiety greatly affected potency. The nonhydrolyzable analogue $\beta \gamma$-methylene ATP was much less potent with a concentration as high as $1 \mathrm{mM}$ producing less than a twofold change in $\left[\mathrm{Ca}^{2+}\right]$. Conversely, another poorly hydrolyzable analog, ATP $\gamma \mathrm{S}$, characterized by thio-substitution of a nonbridging oxygen on the terminal phosphate was only slightly less potent than ATP. As might be expected, potency was significantly affected by substitution of the adenine moiety with other purines and pyrimidine bases. While most other nucleotide triphosphates were two to three times less potent than ATP, UTP was nearly equipotent with ATP $\left(\mathrm{EC}_{50}\right.$ $=300 \mathrm{nM}$ ).

Binding studies and immunofluorescent measurements have indicated that undifferentiated HL-60 cells express only low numbers of receptors for chemotactic formylated peptides. In HL-60 cell cultures, the percentage of cells expressing significant numbers of such receptors is greatly increased under culture conditions which induce differentiation of the cells along either the neutrophil or monocyte pathway (22). Fig. 2 compares the changes in cytosolic $\left[\mathrm{Ca}^{2+}\right]$ triggered by either ATP or FMLP in undifferentiated HL-60 cells, and in cells differentiated by a 48 -h exposure to $0.5 \mathrm{mM}$ dibutyryl cyclic 

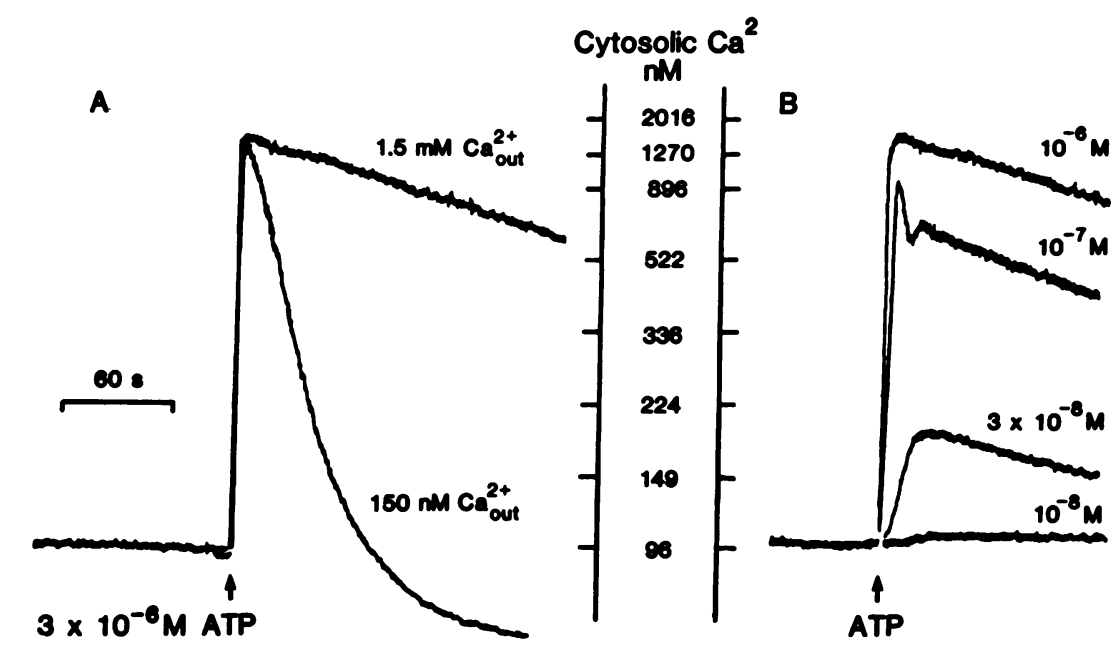

Figure 1. ATP-induced changes in the cytosolic $\left[\mathrm{Ca}^{2+}\right]$ of undifferentiated HL- 60 human promyelocytic leukemia cells: Effects of extracellular $\left[\mathrm{Ca}^{2+}\right]$ and $[\mathrm{ATP}]$. Cytosolic $\left[\mathrm{Ca}^{2+}\right]$ was measured in Fura 2-loaded, undifferentiated HL-60 cells as described in Methods. Each transient was recorded from a separate aliquot of cells $\left(3 \times 10^{5} /\right.$ $\mathrm{ml}$ ) preincubated (with continuous stirring) at $37^{\circ} \mathrm{C}$ for $5 \mathrm{~min}$ before the addition of the indicated concentrations of extracellular ATP. $(A)$ The $\mathrm{Ca}^{2+}$ transients elicited by $3 \mu \mathrm{M}$ ATP when the cells were incubated in either medium containing $1.5 \mathrm{mM}$ extracellular $\left[\mathrm{CaCl}_{2}\right]$ or in medium wherein the extracellular $\left[\mathrm{Ca}^{2+}\right]$ was reduced to $\sim 150 \mathrm{nM}$ (by the addition of $3 \mathrm{mM}$ EGTA) $5 \mathrm{~s}$ before ATP addition. (B) The $\mathrm{Ca}^{2+}$ transients elicited by submicromolar [ATP]. In both $A$ and $B$, recorded transients are graphically superimposed to facilitate comparison. These ATP-induced transients were recorded from the same preparation of cells but are representative of the results obtained with over 100 separate preparations of Fura 2-loaded cells.

AMP, a condition known to induce expression of large numbers of surface FMLP receptors in $>90 \%$ of the cultured cell population. In the undifferentiated cells (Fig. $2 A$ ), $3 \mu \mathrm{M}$ FMLP produced only a small 1.5 -fold increase in cytosolic

Table I. Relative Effects of Various Nucleotides on $\mathrm{Ca}^{2+}$ Mobilization in HL-60 Cells

\begin{tabular}{lc}
\hline \multicolumn{1}{c}{ Nucleotide } & $\mathrm{EC}_{\text {so }}$ for $\mathrm{Ca}^{2+}$ mobilization $(\mathrm{M})$ \\
\hline Adenine nucleotides & \\
ATP & $1.5 \times 10^{-7}$ \\
ADP & $1 \times 10^{-5}$ \\
AMP & $>3 \times 10^{-4}$ \\
Adenosine & $>3 \times 10^{-4}$ \\
ATP Analogues & $1 \times 10^{-6}$ \\
ATP $\gamma$ S & $>1 \times 10^{-3}$ \\
AMPPCP & $2 \times 10^{-6}$ \\
Purine nucleotide triphosphates & $2 \times 10^{-5}$ \\
ITP & $3 \times 10^{-5}$ \\
XTP & \\
GTP & $3 \times 10^{-7}$ \\
Pyrimidine nucleotide triphosphates & $5 \times 10^{-5}$ \\
UTP & $8 \times 10^{-5}$ \\
CTP & \\
TTP & \\
\hline
\end{tabular}

The cytosolic $\left[\mathrm{Ca}^{2+}\right]$ in Fura 2-loaded samples of undifferentiated HL-60 cells was measured at $37^{\circ} \mathrm{C}$ as described in Methods. Separate aliquots of cells were exposed to various concentrations of the indicated nucleotides and the resultant $\mathrm{Ca}^{2+}$ transients were recorded as illustrated in Fig. 1. The peak changes in cytosolic $\left[\mathrm{Ca}^{2+}\right]$ were calculated from these transients and plotted as a function of extracellular nucleotide concentration as illustrated in Fig. $2 ; \mathrm{EC}_{50}$ values were estimated from these dose-response curves. For each nucleotide class, the listed $\mathrm{EC}_{50}$ values were obtained from the data collected from a single preparation of cells, i.e., the adenine nucleotide data was obtained with one cell preparation, the purine nucleotide data was obtained with a separate cell preparation, etc. However, for each nucleotide, similar $\mathrm{EC}_{50}$ values (within a factor of 2) were obtained in least three separate experiments performed over a 12-month interval. Abbreviation: AMPPCP, $\beta \gamma$-methylene ATP.
$\left[\mathrm{Ca}^{2+}\right]$ while $3 \mu \mathrm{M}$ ATP triggered a 13-fold increase. Conversely, in the differentiated cells, [FMLP] $>100 \mathrm{nM}$ triggered $\mathrm{Ca}^{2+}$ transients with peak changes in $1-2 \mu \mathrm{M}$ range (Fig. $2 \mathrm{~B}$ ). The $\mathrm{EC}_{50}$ for FMLP-induced $\mathrm{Ca}^{2+}$ mobilization was $\sim 10 \mathrm{nM}$. Significantly, these differentiated HL-60 cells also responded to extracellular ATP with $\mathrm{Ca}^{2+}$ transients which were indistinguishable, with regard to time courses and magnitudes, from those triggered by FMLP.

Flow cytometric studies facilitated measurement of ATPor FMLP-induced $\mathrm{Ca}^{2+}$ transients in the individual Indo-1 loaded cells comprising either undifferentiated (Fig. 3) or differentiated (not shown) populations of HL-60 cells. In these and most subsequent studies, high (10-30 $\mu \mathrm{M})$ concentrations of FMLP were utilized to ensure maximal occupancy of all available FMLP receptors. The respective two-dimensional (Fig. 3, $A$ and $D$ ) and three-dimensional (Fig. 3, $B$ and $E$ ) contour plots of the Indo-1 fluorescence ratio (increased ratio is indicative of increased cytosolic $\left[\mathrm{Ca}^{2+}\right]$ ) in the individual cells was measured at various times after addition of either ATP (Fig. 3, $A$ and $B$ ) or FMLP (Fig. 3, $D$ and $E$ ). These time-courses were very similar to the FMLP- and ATP-induced changes in Fura-2 fluorescence measured in suspensions of undifferentiated HL-60 cells (Fig. $2 A$ ). Analysis of these and similar recordings indicated that $94 \pm 1 \%(n=3)$ of the undifferentiated cells responded to ATP while $69 \pm 7 \%(n=3)$ of cells showed a response to FMLP. However, while the majority of the cells responded to both agonists, the average magnitude of the ATP-induced changes in $\left[\mathrm{Ca}^{2+}\right]$ were much larger at all times than those triggered by FMLP. Histograms constructed from the data accumulated between 35 and $60 \mathrm{~s}$ after agonist addition (Fig. 3, $C$ and $F$ ) showed that ATP induced a fourfold mean increase in the Indo-1 fluorescence ratio while FMLP triggered only a 1.5 -fold mean increase.

Effects of extracellular ATP on cytosolic $\left[\mathrm{Ca}^{2+}\right]$ in normal blood-and marrow-derived human leukocytes. As shown in Fig. 4, $C$ and $D$ and Table II, micromolar concentrations of extracellular ATP also triggered significant increases in the cytosolic $\left[\mathrm{Ca}^{2+}\right]$ of neutrophils and monocytes. In both cell types, $\mathrm{Ca}^{2+}$ transients induced by ATP were equal in magnitude to those elicited by supramaximal concentrations of FMLP (30 $\mu \mathrm{M})$, PAF (90 nM) (not shown), and $\mathrm{LTB}_{4}(300$ 

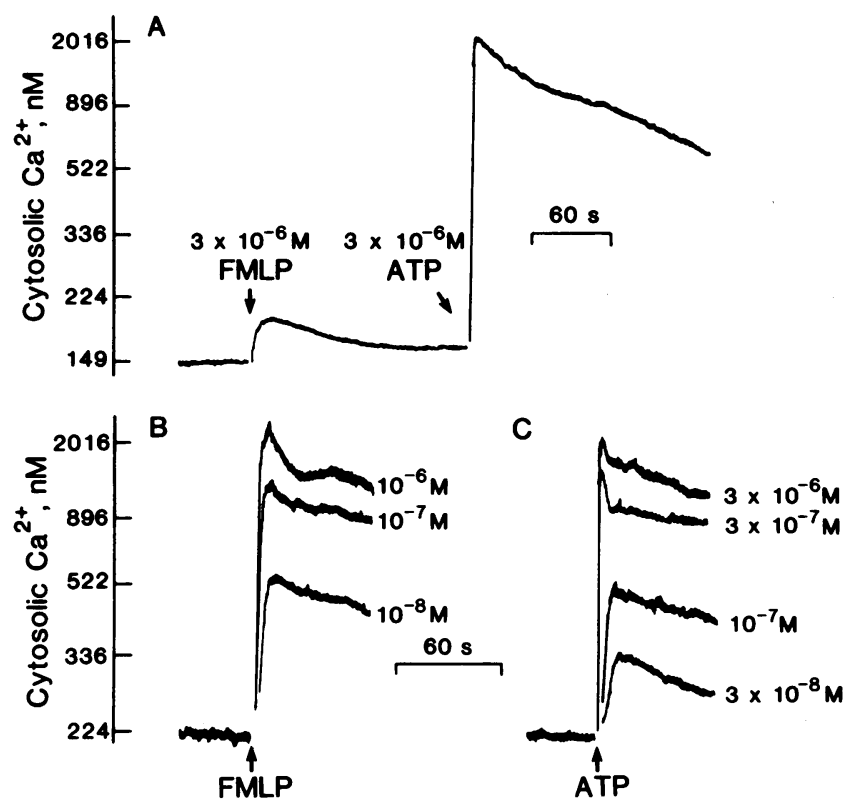

Figure 2. Comparative effects of ATP and chemotactic peptide on the cytosolic $\left[\mathrm{Ca}^{2+}\right]$ of undifferentiated and differentiated HL-60 cells. A culture of undifferentiated HL-60 cells was split into two $25-\mathrm{ml}$ fractions $\left(5 \times 10^{5} / \mathrm{ml}\right)$; one fraction was supplemented with $0.5 \mathrm{mM}$ dibutyryl cyclic AMP while the other was left untreated. Both fractions were then incubated under tissue culture conditions for an additional $48 \mathrm{~h}$; the cells from each fraction were then washed and loaded with Fura 2 as described in Methods. $\mathrm{Ca}^{2}$-dependent Fura 2 fluorescence was recorded as described during incubation of cell aliquots at $37^{\circ} \mathrm{C}$. These results are representative of five similar experiments using separate preparations of dibutyryl cyclic AMP-treated cells. $(A)$ An aliquot of the untreated HL-60 cells was sequentially exposed to $3 \mu \mathrm{M}$ of the chemotactic peptide, FMLP, followed by $3 \mu \mathrm{M}$ ATP. (B) Separate aliquots of the treated HL-60 cells were exposed to the indicated concentrations of ATP. Three recorded transients are graphically superimposed for comparison. $(C)$ Additional aliquots of the treated cells were exposed to the indicated concentrations of FMLP. Five recorded transients are graphically superimposed for comparison.

nM) (not shown). In contrast, peripheral blood lymphocytes (Fig. $4 \mathrm{E}$; Table II) were unresponsive to either extracellular ATP or FMLP.

A variety of experimental manipulations strongly suggested that the ATP-induced $\mathrm{Ca}^{2+}$ transients observed in both neutrophils and monocytes were very similar to those observed in both undifferentiated and differentiated HL-60 cells. ATP elicited increases in neutrophil and monocyte cytosolic $\left[\mathrm{Ca}^{2+}\right]$ resulting from both mobilization of intracellular stores, and influx of extracellular $\mathrm{Ca}^{2+}$. Significant ATP-induced $\mathrm{Ca}^{2+}$ transients were observed even when neutrophils were incubated in medium containing a low $(0.3 \mathrm{mM})$ concentration of $\mathrm{CaCl}_{2}$ to which $6 \mathrm{mM}$ EGTA was added $30 \mathrm{~s}$ before pulsing with ATP (Fig. $5 \mathrm{~B}$ ); under these conditions, the free extracellular $\left[\mathrm{Ca}^{2+}\right]$ was $<10 \mathrm{nM}$. Monocytes were characterized by considerably smaller ATP- and FMLP-induced $\mathrm{Ca}^{2+}$ transients. This was apparently the result of smaller intracellular $\mathrm{Ca}^{2+}$ stores, since both ATP (Fig. $5 \mathrm{D}$ ) and the $\mathrm{Ca}^{2+}$ ionophore ionomycin (not shown) elicited release of only small stores of intracellular $\mathrm{Ca}^{2+}$ when monocytes were incubated in medium containing $<10 \mathrm{nM}$ free $\left[\mathrm{Ca}^{2+}\right] . \mathrm{Ca}^{2+}$ influx appeared to play a proportionately greater role in generating the maximal in- crease in cytosolic $\left[\mathrm{Ca}^{2+}\right]$ in monocytes stimulated with ATP (or FMLP). ATP was a somewhat less potent $\mathrm{Ca}^{2+}$-mobilizing agonist in neutrophils than in HL-60 cells (Fig. $5 \mathrm{~A}$ ); the observed $\mathrm{EC}_{50}$ was $\sim 4 \mu \mathrm{M}$. Additional studies (Fig. $5 \mathrm{C}$ ) showed that ATP concentrations as low as $1 \mu \mathrm{M}$ could trigger measurable changes in $\left[\mathrm{Ca}^{2+}\right]$ in monocytes. Selectivity studies utilizing both neutrophils and monocytes (data not shown) demonstrated that (a) UTP was near equipotent to ATP; $(b)$ ATP was much more potent that ADP, AMP, or adenosine; and (c) the nonhydrolyzable analogue $\mathrm{ATP} \gamma \mathrm{S}$ was near equipotent to ATP.

In total blood mononuclear cell fractions (Fig. $4 \mathrm{~B}$ ) composed of $\sim 90 \%$ lymphocytes and $10 \%$ monocytes, ATP elicited small, 1.4-fold mean increases in cytosolic $\left[\mathrm{Ca}^{2+}\right]$, equal in magnitude to those elicited by FMLP. Removal of monocytes (by adherence) resulted in near total elimination of both ATP and FMLP responsive cells. This further suggested that the ATP responsiveness in mononuclear cell fractions of normal peripheral blood was restricted to the monocyte subpopulation. Similar studies were performed with total mononuclear cell fractions isolated from the bone marrow of normal donors and from the marrow of nonleukemic patients undergoing autologous bone marrow transplantation. Such marrow mononuclear cell preparations are composed of lymphocytes, monocytes, erythroid precursors, lymphocyte precursors, monocyte precursors, and those neutrophil precursors which are less mature than band neutrophils. Sullivan et al. (27) have demonstrated that normal human myeloid progenitor cells, at the myeloblast through promyelocyte stages, do not exhibit significant $\mathrm{Ca}^{2+}$ mobilization in response to FMLP. ATP (10-100 $\mu \mathrm{M})$ stimulated nearly threefold rises in cytosolic $\left[\mathrm{Ca}^{2+}\right]$ in contrast to the 1.2 -fold mean increases induced by 30 $\mu \mathrm{M}$ FMLP (Fig. $4 F$, Table II). These results suggested that bone marrow contains leukocyte precursor cells which could be stimulated by ATP but not by FMLP.

Effects of extracellular ATP on cytosolic $\left[\mathrm{Ca}^{2+}\right]$ in other myelogenous and nonmyelogenous human leukemia cell lines. In order to establish which types of hematopoietic progenitor cells expressed a $\mathrm{Ca}^{2+}$-mobilizing response to extracellular ATP, a number of established human leukemic cell lines, in addition to the HL-60 promyelocytic leukemia line, were examined (Fig. 4, $M-Q$, Table II). These included the U937 promonocytic line, the KG-1 myeloblastic line, the less differentiated KG-1a myeloblastic line, the Molt-4 lymphoblastic line, the K562 erythroblastic line, and the HuT-78 T-cell lymphoma line. The sequential stages of normal myelomonocytic differentiation to which the various myeloid cell lines correspond are illustrated in Fig. $4 A$. No ATP- (or FMLP) induced changes in $\left[\mathrm{Ca}^{2+}\right]$ were measured in the Molt-4 (Fig. $4 Q$ ), K562 (not shown), or HuT-78 cells (not shown) even with extracellular ATP concentrations as high as $300 \mu \mathrm{M}$. In contrast to the lack of ATP responsiveness in these nonmyelogenous leukemia/lymphoma cells, both the U937 (Fig. $4 O$ ) and KG-1 cells (Fig. $4 M$ ) showed significant $\mathrm{Ca}^{2+}$ mobilization when treated with extracellular ATP. For comparison, the responses of both undifferentiated (Fig. $4 N$ ) and differentiated (Fig. 4 P) HL-60 cells to ATP (and FMLP) are also shown.

Like HL-60 cells, the U937 promonocytic cells exhibited large ATP-induced $\mathrm{Ca}^{2+}$ transients in contrast to the much more modest responses to FMLP (Fig. $4 O$ ). Our observation that extracellular ATP increased cytosolic $\left[\mathrm{Ca}^{2+}\right]$ in the U937 cell line corroborates a recent report by Maudsley and Morris 
A
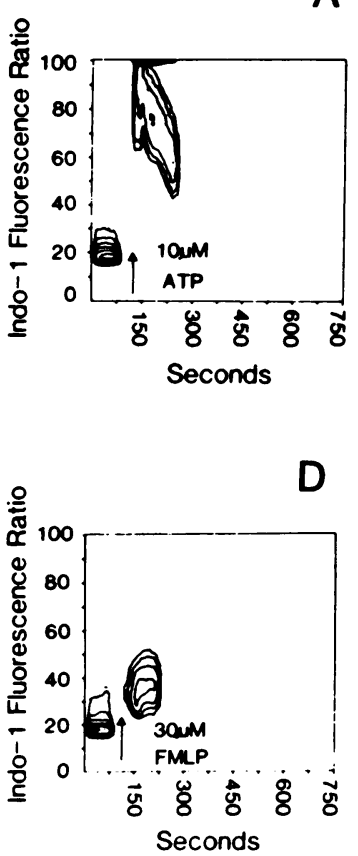

B
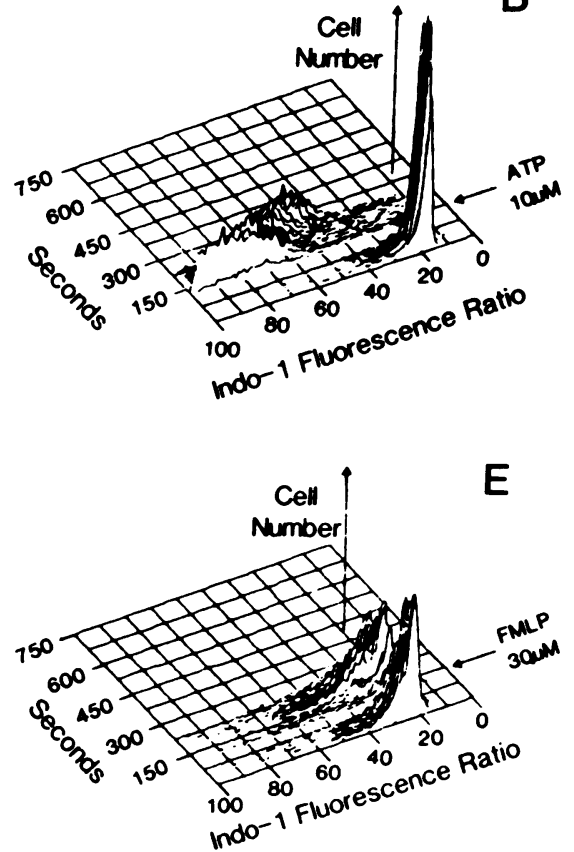

C

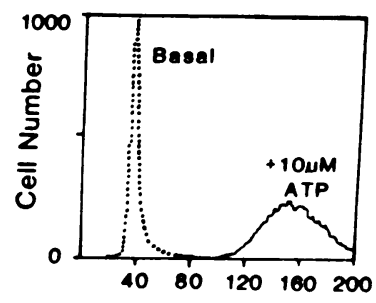

Indo-1 Fluorescence Ratio

Figure 3. Flow cytometric measurements of ATP- or FMLP-induced changes in cytosolic $\left[\mathrm{Ca}^{2+}\right]$ in individual HL-60 cells. Indo-1 loaded HL-60 cells were stimulated at the indicated times with ATP $(A-C)$ or FMLP $(D-F)$ and examined by flow cytometry, as described in Methods. In $A$ and $D$ data are displayed as contour plots of time vs. Indo-1 ratio of violet/blue emission (which is proportional to cytosolic $\left[\mathrm{Ca}^{2+}\right]$ ). In $B$ and $E$ data are displayed as time vs. Indo-1 ratio of violet/blue emission vs. number of cells. $C$ and $F$ display histograms of the ratio of Indo-1 violet/blue emission vs. number of cells for HL-60 cells prior to stimulation (dotted lines) and for cells during the period 35-60 s after addition of agonist (solid lines).

(28). Flow cytometric studies of Indo-1-loaded U937 cells indicated that $91 \pm 1 \%(n=3)$ showed ATP-induced $\mathrm{Ca}^{2+}$ transients while only $21 \pm 4 \%(n=3)$ of the cells responded weakly to FMLP. In contrast to the very large ATP-induced $\mathrm{Ca}^{2+}$ transients in HL-60 and U937 cells, cells from the less mature KG-1 myeloblastic line (Fig. $4 M$ ) exhibited a smaller, twofold mean increase in cytosolic $\left[\mathrm{Ca}^{2+}\right]$ upon stimulation with 100 $\mu \mathrm{M}$ ATP; these cells were completely unresponsive to $30 \mu \mathrm{M}$ FMLP. KG-1 cells did contain large intracellular $\mathrm{Ca}^{2+}$ stores which when released by the $\mathrm{Ca}^{2+}$ ionophore ionomycin, when the cells were incubated in low $\left[\mathrm{Ca}^{2+}\right]$ containing buffer, resulted in greater than a fivefold increase in cytosolic $\left[\mathrm{Ca}^{2+}\right]$ (data not shown). Flow cytometric measurements revealed that only $20 \pm 1 \%(n=3)$ of KG-1 cells responded to $100 \mu \mathrm{M}$ ATP, and that the increases in cytosolic $\left[\mathrm{Ca}^{2+}\right]$ induced in those cells was small. The less mature KG-1A cell line (a variant of the KG-1 cell line) (29) was even less responsive to 100 $\mu \mathrm{M}$ ATP (not shown) with less than 1.1-fold increases in $\left[\mathrm{Ca}^{2+}\right]$ being observed. As was found with $\mathrm{KG}-1$ cells, these KG-1A cells were completely unresponsive to $30 \mu \mathrm{M}$ FMLP. This suggests perhaps only a subpopulation of KG-1 cells, slightly more mature than the majority of cells in culture, express functionally significant numbers of the putative ATP receptor sites.

Effects of extracellular ATP on cytosolic $\left[\mathrm{Ca}^{2+}\right]$ in peripheral blood leukocytes isolated from patients with myelogenous and nonmyelogenous leukemias. The total mononuclear cell fraction of blood from patients with leukemia is predominated by hematopoietic progenitor cells at specific stages of differentiation (the cell composition depending on the type of leuke- mia, cf. Fig. $1 A$ ). Therefore, as with the established cell lines, large numbers of particular types of immature cells, normally found only in the bone marrow, could be studied. The ATPand FMLP-induced $\mathrm{Ca}^{2+}$ transients observed in these various leukemic cell preparations are illustrated in Fig. 4, G-L; these transients should be compared with those observed with the total mononuclear cell fraction isolated from a normal, nonleukemic blood sample (Fig. $4 \mathrm{~B}$ ).

As observed with the KG-1 myeloblastic cells, myeloblasts isolated from the blood of patients with leukemia of the FAB (25) classification M1 (FAB M1) responded to $100 \mu \mathrm{M}$ ATP with modest, twofold mean increases in cytosolic $\left[\mathrm{Ca}^{2+}\right]$, and were totally unresponsive to $30 \mu \mathrm{M}$ FMLP (Fig. $4 G$, Table II). At all postmyeloblast stages of differentiation, both neutrophil and monocyte progenitor cells exhibited large (5-20-fold) increases in $\left[\mathrm{Ca}^{2+}\right]$ in response to ATP; these transients were characterized by complete mobilization of ionomycin-releasable intracellular $\mathrm{Ca}^{2+}$ stores. These cell populations included the blood mononuclear cells from patients with $(a)$ promyelocytic leukemia (FAB-M3) (Fig. $4 \mathrm{H}$ ); (b) chronic myelogenous leukemia in chronic phase (30) (Fig. $4 \mathrm{~L}$; Table II); and (c) myelomonocytic leukemia (FAB-M4) (Fig. 4 I). In all these cell populations, FMLP elicited considerably smaller $\mathrm{Ca}^{2+}$ transients. Flow cytometric studies confirmed the presence of large numbers of ATP-responsive, but FMLP-unresponsive, cells in these leukemic cell populations. For example, $76 \%$ of the mononuclear blood cells isolated from a patient with myelomonocytic leukemia responded to ATP while $<1 \%$ responded to FMLP (Fig. 6). Finally, the total mononuclear blood cell fractions isolated from patients with the more dif- 


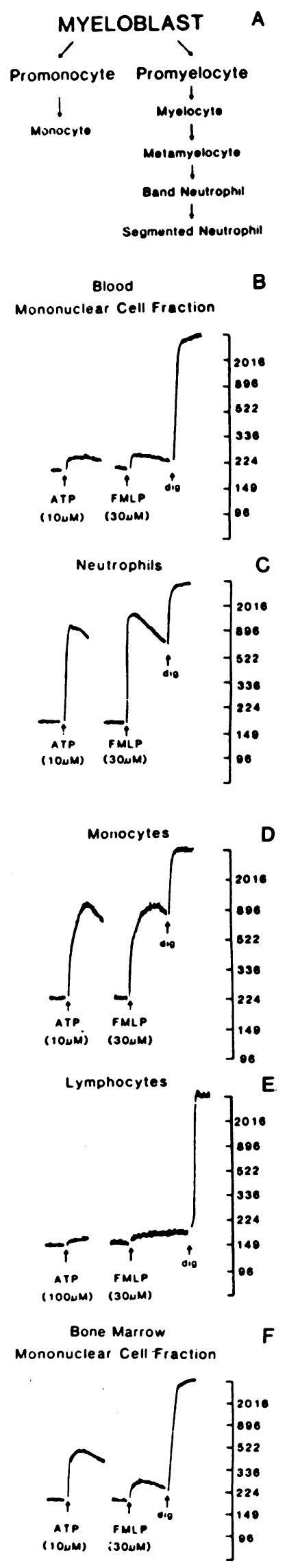

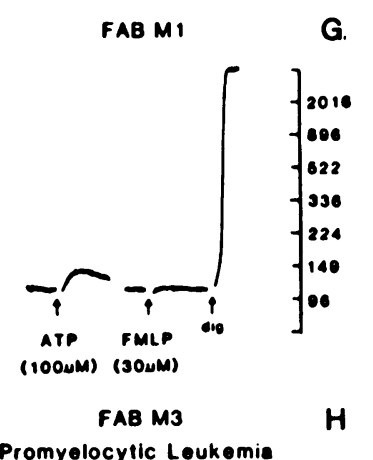

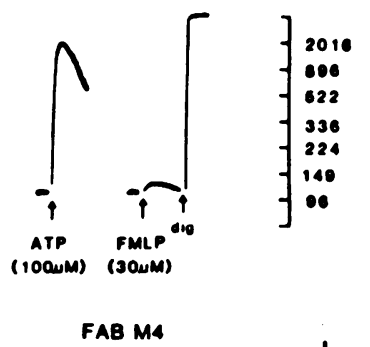

Myelomonocytic Leukemia I.

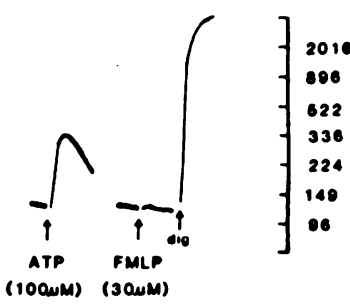

FAB MS

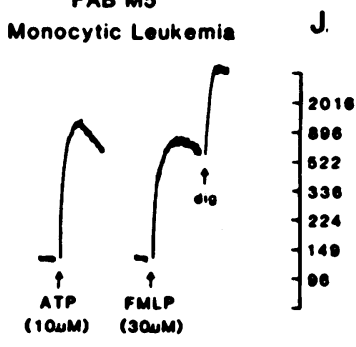

Chronic Lymphocytic Leukemia $K$

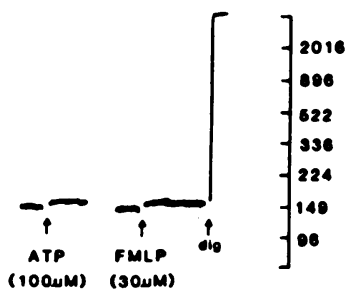

Chronic Phase L Chronic Myelogenous Leukemia

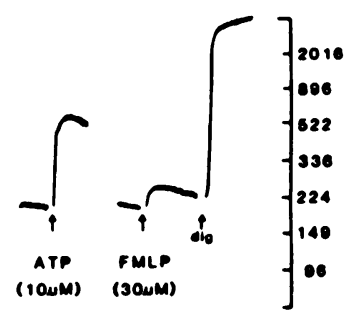

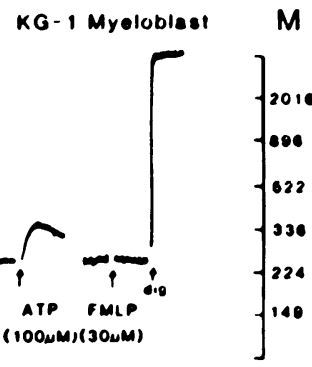

HL-60 Promyelocyto

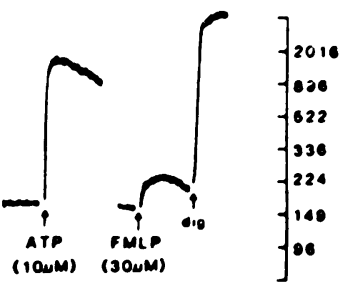

U937 Promonocyte 0

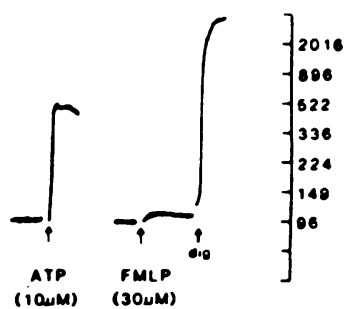

Differentiated ML60

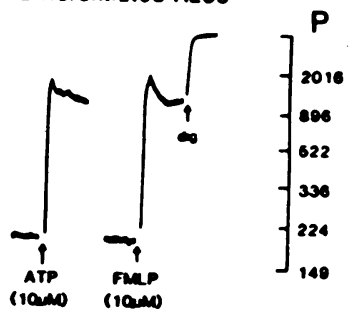

Molt-4 Lymphoblast

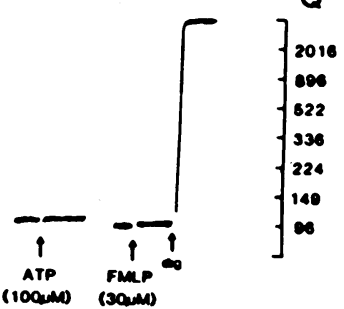
ATP
(10040) Finp

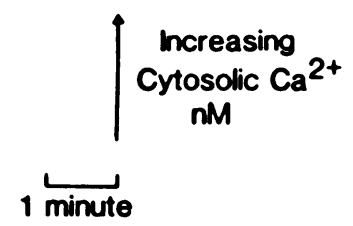




\begin{tabular}{|c|c|c|c|c|}
\hline \multirow[b]{2}{*}{ Cell type } & \multirow[b]{2}{*}{ Basal $\left[\mathrm{Ca}^{2+}\right]$} & \multicolumn{3}{|c|}{ Peak change in cytosolic $\left[\mathrm{Ca}^{2+}\right]$ agonist } \\
\hline & & $100 \mu \mathrm{M}$ АТP & $10 \mu \mathrm{M} \mathrm{ATP}$ & $30 \mu \mathrm{M}$ FMLP \\
\hline & \multicolumn{4}{|c|}{$n M$} \\
\hline Neutrophils & $176 \pm 17$ & $1729 \pm 226$ & $1662 \pm 74$ & $1797 \pm 258(3)$ \\
\hline Monocytes & $197 \pm 23$ & $1388 \pm 397$ & $1136 \pm 344$ & $1447 \pm 254(3)$ \\
\hline Lymphocytes & $150 \pm 12$ & $156 \pm 9$ & ND & $167 \pm 3(3)$ \\
\hline Normal blood (mononuclear) & $205 \pm 16$ & $282 \pm 17$ & $270 \pm 20$ & $280 \pm 14(7)$ \\
\hline KG-1 (myeloblasts) & $142 \pm 19$ & $265 \pm 40$ & $168 \pm 18$ & $142 \pm 19(7)$ \\
\hline AML (FAB M1) & $13 \dot{6} \pm 17$ & $263 \pm 97$ & $179 \pm 30$ & $138 \pm 19(3)$ \\
\hline HL-60 (promyelocytes) & $200 \pm 20$ & $>2000$ & $>2000$ & $303 \pm 32(3)$ \\
\hline Promyelocytic leukemia (FAB M3) & 67 & 1269 & 672 & $96(1)$ \\
\hline Chronic myelogenous leukemia (chronic phase) & $180 \pm 20$ & $1173 \pm 375$ & $1062 \pm 403$ & $365 \pm 93(4)$ \\
\hline Normal mononuclear bone marrow & $170 \pm 28$ & $455 \pm 75$ & $357 \pm 39$ & $212 \pm 22(6)$ \\
\hline U937 (promonocytes) & $135 \pm 5$ & $872 \pm 67$ & $724 \pm 98$ & $159 \pm 10(4)$ \\
\hline Myelomonocytic leukemia (FAB M4) & 137 & 416 & 233 & $137(1)$ \\
\hline Monocytic leukemia (FAB M5) & $123 \pm 38$ & $856 \pm 580$ & $817 \pm 639$ & $656 \pm 339(2)$ \\
\hline B cell chronic lymphocytic leukemia & $157 \pm 9$ & $166 \pm 10$ & $165 \pm 10$ & $164 \pm 10(7)$ \\
\hline Acute lymphocytic leukemia (FAB L2) & 156 & 176 & 156 & $156(1)$ \\
\hline
\end{tabular}

Each data point represents the mean \pm standard error of $(n)$ experiments.

ferentiated monocytic leukemia (FAB-M5), like mature monocytes, responded to both ATP and FMLP with large, equivalent $\mathrm{Ca}^{2+}$ transients (Fig. $4 J$ ).

The ability of leukemic blood cells to mobilize $\mathrm{Ca}^{2+}$ in response to stimulation with ATP was restricted to cells isolated from patients with myeloid leukemias. Blood cells isolated from patients with B cell chronic lymphocytic leukemia (Fig. $4 \mathrm{~K}$; Table II) and cells isolated from a patient with acute lymphocytic leukemia (Table II) were totally unresponsive to both $100 \mu \mathrm{M}$ ATP and $30 \mu \mathrm{M}$ FMLP. Therefore, as shown with the leukemic cell lines, responsiveness to ATP was not merely a general characteristic of transformed leukocytes.

\section{Discussion}

Rapid elevation of cytosolic $\left[\mathrm{Ca}^{2+}\right]$ by micromolar concentrations of extracellular ATP has now been observed in a large number of nontransformed and transformed cell types (8-11). In the majority of these cell types the $\mathrm{Ca}^{2+}$-mobilizing action of extracellular ATP has been correlated with the ability of ATP to elicit rapid breakdown of inositol phospholipids with consequent accumulation of the $\mathrm{Ca}^{2+}$-mobilizing $(1,4,5)$ trisphosphate isomer of myo-inositol (31). We have previously demonstrated a similar correlation between ATP-induced
$\mathrm{Ca}^{2+}$ mobilization and inositol phospholipid breakdown in both undifferentiated and differentiated HL-60 cells (18). In all ATP-responsive leukocyte types tested in this study, $0.1-100 \mu \mathrm{M}$ ATP triggered rapid mobilization of intracellular $\mathrm{Ca}^{2+}$ stores as well as enhanced influx of extracellular $\mathrm{Ca}^{2+}$. This strongly suggests that the ATP-induced increases in cytosolic $\left[\mathrm{Ca}^{2+}\right]$ observed in these various human leukocyte types is due to the expression of a common $\mathrm{P}_{2}$-purinergic receptor subtype which has micromolar affinity for ATP and which is functionally coupled to the inositol phospholipid-specific phospholipase $\mathrm{C}$ effector system. Thus, the effects of extracellular ATP on cytosolic $\left[\mathrm{Ca}^{2+}\right]$ of the leukocytes described in this study should be distinguished from the plasma membrane-permeabilizing effects produced by millimolar levels of extracellular ATP in mast cells (32), transformed fibroblasts (33), and the J774 murine macrophage line $(34,35)$.

These results also indicate that the expression of these putative ATP receptors may be a common feature of human phagocytic leukocytes and phagocyte progenitor cells. Occupation of these extracellular recognition sites for ATP produced significant increases in the cytosolic $\left[\mathrm{Ca}^{2+}\right]$ of neutrophils, monocytes, promyelocytes, promonocytes, and at least certain myeloblast subtypes (Fig. 4). Conversely, no ATP-induced $\mathrm{Ca}^{2+}$ transients were observed in normal lymphocytes,

Figure 4. ATP-induced changes in cytosolic $\left[\mathrm{Ca}^{2+}\right]$ in normal human leukocytes, leukemic leukocytes, and established human leukemia cell lines. Column $1(A-F)$ details results obtained with normal human leukocytes which were isolated from the blood $(B-E)$ or marrow $(F)$ of healthy donors and fractionated into the total mononuclear fraction $(B)$ and polymorphonuclear fraction or neutrophils $(C)$ using conventional Ficoll-Hypaque separation protocols (35). The total mononuclear fraction was further fractionated into a $>85 \%$ monocyte-enriched population $(D)$ and the lymphocyte population $(E)$. The total mononuclear fraction was also isolated from the bone marrow of nonleukemic donors $(F)$. Column $2(G-L)$ details the results obtained using the total mononuclear leukocyte fractions freshly isolated from the blood of patients with various diagnosed leukemias. These transients should be compared with those observed in total mononuclear cell fraction $(B)$ derived from non-leukemic donors. Column $3(M-Q)$ details the results obtained using a variety of established human leukemia cell lines. All cell types were loaded with Fura 2 and the cytosolic $\left[\mathrm{Ca}^{2+}\right]$ levels were measured as previously described. For each cell type, the responses to both ATP (10 or $100 \mu \mathrm{M})$ and FMLP $(30 \mu \mathrm{M})$ are illustrated. 


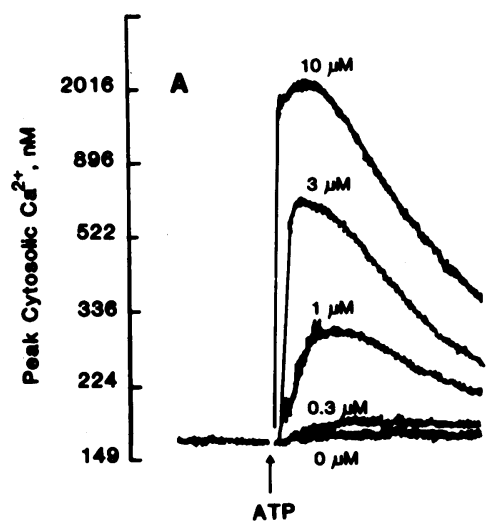

-

C
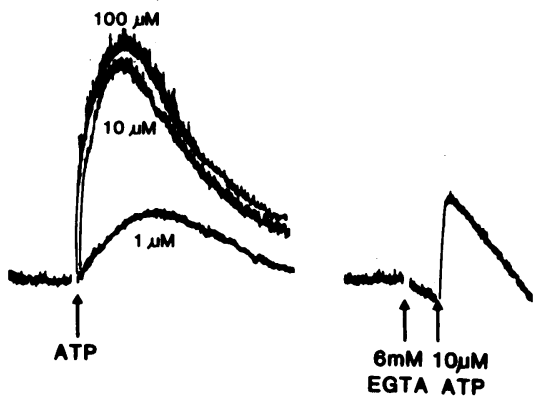

Figure 5. Comparative effects of extracellular ATP on the cytosolic $\left[\mathrm{Ca}^{2+}\right]$ of human peripheral blood neutrophils and monocytes: Doseresponse relationships and effect of removal of extracellular calcium. Human neutrophils $(A, B)$ or monocytes $(C, D)$ were isolated and loaded with Fura 2 as described in Methods. $\mathrm{Ca}^{2+}$-dependent fura 2 fluorescence was recorded during incubation of cell aliquots $(3$ $\times 10^{5} / \mathrm{ml}$ ) at $37^{\circ} \mathrm{C}$. The illustrated transients were recorded from a single preparation of neutrophils but are representative of the transients obtained using 9 separate preparations of neutrophils isolated from six blood donors. ( $A$ and $C$ ) Separate aliquots of neutrophils $(A)$ or monocytes $(C)$ were treated with the indicated concentrations of extracellular ATP; transients are graphically superimposed for comparison. These transients were recorded from cells incubated in medium containing $1.5 \mathrm{mM} \mathrm{CaCl}_{2}$. $(B$ and $D)$ The free extracellular $\left[\mathrm{Ca}^{2+}\right]$ was reduced to $<60 \mathrm{nM}$ by the addition of $6 \mathrm{mM}$ EGTA $20 \mathrm{~s}$ before the addition of $10 \mu \mathrm{M}$ ATP $(A)$ or $100 \mu \mathrm{M}$ ATP $(D)$.

lymphocytic leukemia cells (chronic and acute), and established human cell lines with lymphoblastic, lymphoma, or erythroblastic phenotypes. Significantly, while these various nonmyelogenous leukemic cell types did not respond to ATP, the total mononuclear cell fraction isolated from normal human bone marrow contained a significant fraction of cells which did exhibit large ATP-induced changes in cytosolic $\left[\mathrm{Ca}^{2+}\right]$. This strongly suggested that ATP-induced $\mathrm{Ca}^{2+}$ mobilization is a characteristic of normal neutrophil/monocyte progenitor cells, and is not a general characteristic of leukemic cells.

Even relatively immature myeloid progenitor cells such as myeloblasts exhibited small, but significant, ATP-induced changes in $\left[\mathrm{Ca}^{2+}\right]$. However, not all types of presumptive myeloblasts were equally responsive to ATP as demonstrated by the flow cytometric studies of the KG-1 myeloblast cell line which indicated that only a subpopulation of this myeloblast cell line exhibited measurable ATP-induced $\mathrm{Ca}^{2+}$ transients, and by the lack of ATP-responsiveness in the less mature KG-1 A myeloblast cell line. In contrast, nearly $100 \%$ of those neutrophil and monocyte progenitor cells which were more mature than myeloblasts, responded to ATP with large $\mathrm{Ca}^{2+}$ transients representing near total mobilization of ionomycin releasable $\mathrm{Ca}^{2+}$ stores. A plausible interpretation of these results is that myeloid progenitor cells begin to express ATP receptors shortly after entry into the myeloblast stage but that the number of receptors per cell reaches a functionally significant number just before differentiation of myeloblasts into promyelocytes/promonocytes. Conversely, it appears that functionally significant numbers of FMLP receptors are expressed only at later stages (metamyelocytes/post-promonocyte) of differentiation.

It should be emphasized that the magnitude of response elicited by ATP was correlated with the degree to which individual cells in a sample had differentiated. Depending on the FAB classification (25) blood cells isolated from leukemic patients are composed of one or more immature cell types. The relative cell type composition in blood samples collected from several patients with the same FAB classification can therefore vary considerably. For example, cells isolated from patients with leukemias classified as FAB-M3 were composed of various relative combinations of myeloblasts and promyelocytes. The population response to ATP reflected the percentage of promyelocytes in a sample. When the percentage of promyelocytes was large, as was the case with the sample shown in Fig. $4 H$ (43\% promyelocytes and $40 \%$ myeloblasts) the ATP response was large. However, blood cells isolated from two other patients classified as FAB M3 contained nearly all myeloblasts. These cells consequently responded like myeloblasts with small increases in cytosolic $\left[\mathrm{Ca}^{2+}\right]$. The efficacy of ATP in triggering increases in $\left[\mathrm{Ca}^{2+}\right]$ is therefore a reflection of neutrophil/monocyte cell differentiation, and not of particular leukemic abnormalities. It should be noted that the relative responses to both ATP and FMLP of normal marrow-derived mononuclear cells (Fig. $4 F$ ) were very similar to those observed in blood-derived mononuclear cells from patients the chronic phase of chronic myelogenous leukemia (Fig. $4 \mathrm{~L}$ ). This similarity is not surprising since both cell populations contained neutrophil precursor cells at the same stages of differentiation (from myeloblast to metamyelocyte).

It appears likely that activation of the inositol phospholipid signalling cascade by extracellular ATP might have a physiological role in modulating the integrated inflammatory responses of neutrophils and monocytes. Both Ward et al. (20) and Kuhns et al. (21) have reported that micromolar ATP primes neutrophils for enhanced superoxide release in response to stimulation with immune complexes and FMLP. Moreover, in vitro studies by Ward et al. (36) have demonstrated that activated platelets (suspended at cytocrits present in blood) can release the quantities of ATP necessary to elicit this priming action.

In contrast to the equivalent $\mathrm{Ca}^{2+}$-mobilization triggered by ATP, FMLP, $\mathrm{LTB}_{4}$, and PAF in mature, circulating phagocytes, only ATP was found to consistently activate increases in cytosolic $\left[\mathrm{Ca}^{2+}\right]$ in neutrophil and monocyte precursors as undifferentiated as myeloblasts. While both FMLP and PAF elicited significant $\mathrm{Ca}^{2+}$ transients in more differentiated progenitor cells (e.g., HL-60 promyelocytes or U937 promonocytes), the peak magnitudes of such transients were invariably smaller 

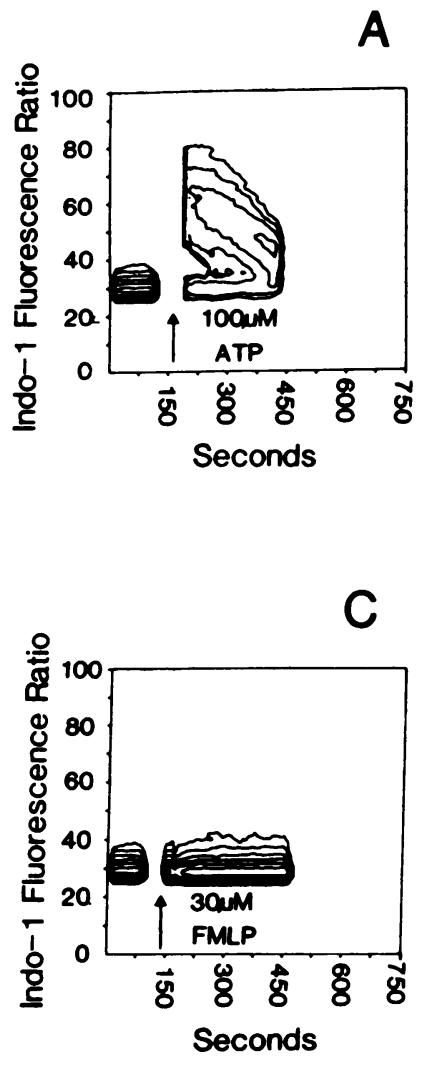
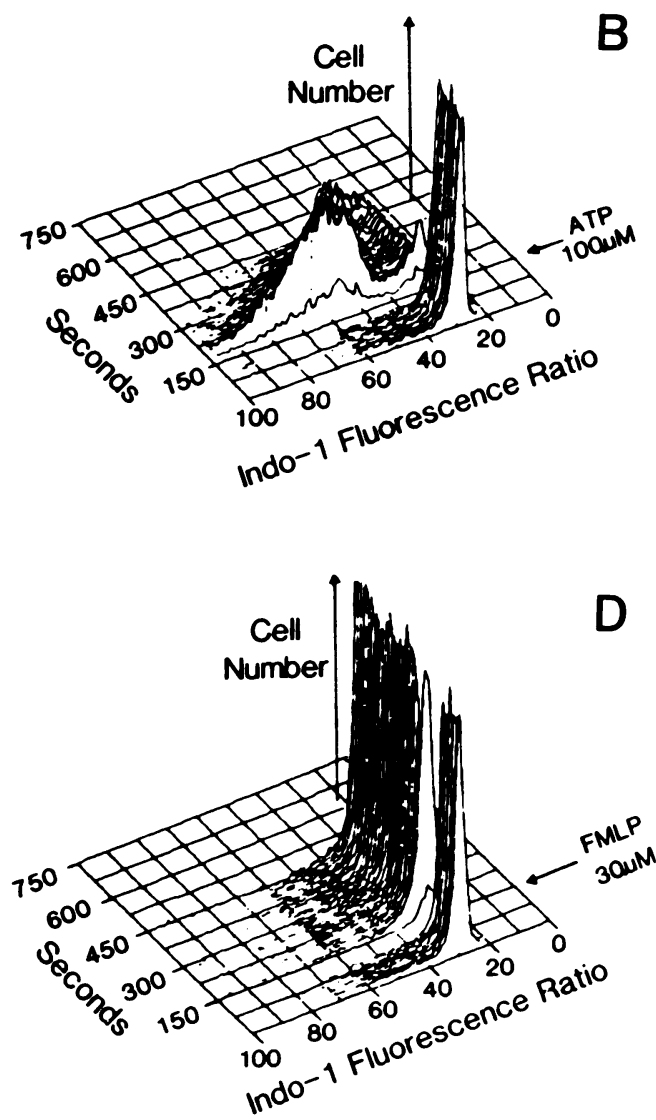

Figure 6. Flow cytometric measurements of ATP- or FMLP-induced changes in cytosolic $\left[\mathrm{Ca}^{2+}\right]$ in individual cells isolated from a patient with FAB M4 leukemia. Indo-1 loaded blood mononuclear cells isolated from a patient with myelomonocytic leukemia (FAB M4), composed of $90 \%$ blasts (myeloblasts and promonocytes) and $10 \%$ lymphocytes, were stimulated at the indicated times with ATP $(A$ and $B)$ or FMLP $(C$ and $D)$ and examined by flow cytometry, as described in Methods. In $A$ and $C$ data are displayed as contour plots of time vs. Indo-1 ratio of violet/blue emission (which is proportional to cytosolic $\left.\left[\mathrm{Ca}^{2+}\right]\right)$. In $B$ and $D$ data are displayed as time vs. Indo-1 ratio of violet/blue emission vs. number of cells. than those triggered by ATP. The ability of such immature cells to respond to ATP raises the possibility that activation of the inositol phospholipid signalling system by ATP may play a functional role during differentiation. In fact, we have observed that ATP is capable of modulating the differentiation of HL-60 and U937 cells under cell culture conditions (Cowen, D. S., M. Berger, and G. R. Dubyak, manuscript submitted for publication). In an early study of retinoic acid effects on HL-60 cell differentiation. Olsson et al. (37) noted that differentiation of these cells was synergistically induced upon cotreatment with extracellular ATP, at micromolar concentrations, and retinoic acid, at nanomolar concentrations. Such in vitro observations lead to speculation as to whether marrow stromal cells may release ATP in the microenvironments of the bone marrow at concentrations sufficient to modulate the function of normal neutrophil/monocyte progenitor cells during the course of differentiation.

\section{Acknowledgments}

We thank Dr. James Jacoberger and Kerri J. Schimenti, Department of Developmental Genetics and Anatomy, Case Western Reserve University, for their technical expertise and assistance in performing the Indo-1 flow cytometric studies.

This work was supported in part by grants GM-36387 and P30CA43703 from the National Institutes of Health. Dr. Cowen is the recipient of a Medical Scientist Training Program Award.

\section{References}

1. Gordon, J. L. 1986. Extracellular ATP: effects, sources, and fate. Biochem. J. 233:309-319.
2. Pearson, J. D., S. B. Coade, and N. J. Cusack. 1985. Characterization of ectonucleotidases on vascular smooth muscle cells. Biochem. J. 230:503-507.

3. Morel, N., and F. M. Meunier. 1981. Simultaneous release of acetylcholine and ATP from stimulated cholinergic synaptosomes. $J$. Neurochem. 36:1766-1773.

4. Rojas, E., H. B. Pollard, and E. Heldman. 1985. Real-time measurements of acetylcholine-induced release of ATP from bovine medullary chromaffin cells. FEBS (Fed. Eur. Biochem. Soc.) Lett. 185:323-327.

5. Ingerman, C. M., J. B. Smith, and M. J. Silver. 1979. Direct measurement of platelet secretion in whole blood. Thromb. Res. 16:335-345.

6. Pearson, J. D., L. L. Slakey, and J. L. Gordon. 1983. Stimulation of prostaglandin production through purinoreceptors on cultured porcine endothelial cells. Biochem. J. 214:273-276.

7. Forsberg, E. J., G. Feuerstein, E. Shohami, and H. B. Pollard. Adenosine triphosphate stimulated inositol phospholipid metabolism and prostacyclin production in adrenal medullary endothelial cells by means of $\mathrm{P}_{2}$-purinergic receptors. Proc. Natl. Acad. Sci. USA. 84:5630-5634.

8. Charest, R., P. F. Blackmore, and J. H. Exton. 1985. Characterization of responses of isolated hepatocytes to ATP and ADP. J. Biol. Chem. 260:15789-15794.

9. Phaneuf, S., P. Berta, J. Casanova, and J.-C. Cavadore. 1987. ATP stimulates inositol phosphates accumulation and calcium mobilization in a primary culture of rat aortic myocytes. Biochem. Biophys. Res. Commun. 143:454-460.

10. Dubyak, G. R. 1986. Extracellular ATP activates polyphosphoinositide breakdown and $\mathrm{Ca}^{2+}$ mobilization in Ehrlich ascites tumor cells. Arch. Biochem. Biophys. 245:84-95.

11. Weiner, E., G. R. Dubyak, and A. Scarpa. 1986. $\mathrm{Na}^{+} / \mathrm{H}^{+}$exchange in Ehrlich ascites tumor cells: regulation by extracellular ATP 
and 12-O-tetradecanoylphorbol 13-acetate. J. Biol. Chem. 261:45294534.

12. Verghese, M. W., C. D. Smith, and R. Snyderman. 1986. Role of guanine nucleotide regulatory protein polyphosphoinositide degradation and activation of phagocytic leukocytes by chemoattractants. $J$. Cell. Biochem. 32:59-69.

13. Verghese, M. W., L. Charles, L. Jakoi, S. B. Dillon, and R. Snyderman. 1987. Role of a guanine nucleotide regulatory protein in the activation of phospholipase $\mathrm{C}$ by different chemoattractants. $J$. Immunol. 138:4374-4380.

14. Smith, C. D., R. J. Uhing, and R. Snyderman. 1987. Nucleotide regulatory protein-mediated activation of phospholipase $\mathrm{C}$ in human polymorphonuclear leukocytes is disrupted by phorbol esters. J. Biol. Chem. 262:6121-6127.

15. Rider, L., and J. E. Niedel. 1987. Diacylglycerol accumulation and superoxide production in stimulated human neutrophils. J. Biol. Chem. 262:5603-5608.

16. Bass, D. A., C. Gerard, P. Olbrantz, J. Wilson, C. E. McCall, and L. C. McPhail. 1987. Priming of the respiratory burst of neutrophils by diacylglycerol. Independence from activation or translocation of protein kinase C. J. Biol. Chem. 262:6642-6649.

17. Barrowman, M. M., S. Cockcroft, and B. D. Gomperts. 1986. Two roles for guanine nucleotides in the stimulus-secretion sequence of neutrophils. Nature (Lond.). 319:504-507.

18. Dubyak, G. R., D. S. Cowen, and L. M. Mueller. 1988. Activation of inositol phospholipid breakdown in HL60 cells by $P_{2}$-purinergic receptors: evidence for mediation by both pertussis toxin-sensitive and -insensitive mechanisms. J. Biol. Chem. 263:18107-18117.

19. Dubyak, G. R., and D. S. Cowen. 1987. Activation of the inositol phospholipid signalling system by extracellular ATP in the HL-60 human promyelocyte cell line and human neutrophils. J. Gen. Physiol. 90:15a. (Abstr.)

20. Ward, P. A., T. W. Cunningham, K. K. McCulloch, and K. W. Johnson. 1988. Regulatory effects of adenosine and adenine nucleotides on oxygen radical responses of neutrophils. Lab. Invest. 58:438447.

21. Kuhns, D. B., D. G. Wright, J. Nath, S. S. Kaplan, and R. E. Basford. 1988. ATP induces transient elevations in $\left[\mathrm{Ca}^{2+}\right]_{i}$ in human neutrophils and primes these cells for enhanced $\mathrm{O}_{2}^{-}$generation. $L a b$. Invest. 58:448-453.

22. Chaplinski, T. J., and J. E. Niedel. 1982. Cyclic nucleotide-induced maturation of human promyelocytic leukemia cells. J. Clin. Invest. 70:953-964.

23. Boyam, A. 1968. Separation of leukocytes from blood and bone marrow. Scand. J. Clin. Invest. 21(Suppl. 97):77-89.

24. Verghese, M. W., K. Fox, L. C. McPhail, and R. J. Snyderman. 1985. Chemoattractant-elicited alterations of cAMP levels in human polymorphonuclear leukocytes require a $\mathrm{Ca}^{2+}$ dependent mechanism which is independent of transmembrane activation of adenylate cyclase. J. Biol. Chem. 260:6769-6775.

25. Bennet, J. M., D. Catovsky, M. T. Daniel, G. Flandrin. 1976. Proposals for the classification of the acute leukemias: the FrenchAmerican-British (FAB) cooperative group. Br. J. Haematol. 33:451458.

26. Rabinovitch, P. S., C. H. June, A. Grossman, and J. A. Ledbetter. 1986. Heterogeneity among $T$ cells in intracellular free calcium responses after mitogen stimulation with PHA or anti-CD3. Simultaneous use of Indo-1 and immunofluorescence with flow cytometry. $J$. Immunol. 137:952-961.

27. Sullivan, R., D. A. Melnick, H. L. Malech, T. Meshulam, E. R. Simons, K. G. Lazzari, P. J. Proto, A-S. Gadenne, J. L. Leavitt, and J. D. Griffin. 1987. The effects of phorbol myristate acetate and chemotactic peptide on transmembrane potentials and cytosolic free calcium in mature granulocytes evolve sequentially as the cells differentiate. J. Biol. Chem. 262:1274-1281.

28. Maudsley, D. G., and A. G. Morris. 1987. Rapid intracellular calcium changes in U937 monocyte line: transient increases in response to platelet-activating factor and chemotactic peptide but not interferon- or lipopolysaccharide. Immunology. 61:189-194.

29. Koeffler, H. P., R. Billing, A. J. Lusis, R. Sparkes, R., and D. W. Golde. 1980. An undifferentiated variant derived from the human acute myelogenous leukemia cell line (KG-1). Blood. 56:265-273.

30. Sokal, J. E., M. Baccarani, D. Russo, and S. Tura. 1976. Staging and prognosis in chronic myelogenous leukemia. Semin. Hematol. 25:49-61.

31. Berridge, M. J. 1987. Inositol trisphosphate and diacylglycerol: Two interacting second messengers. Annu. Rev. Biochem. 56:159-193.

32. Cockcroft, S., and B. D. Gomperts. 1980. The ATP ${ }^{4-}$ receptor of rat mast cells. Biochem. J. 188:789-798.

33. Rozengurt, E., L. A. Heppel, and I. Friedberg. 1977. Effect of exogenous ATP on the permeability properties of transformed cultures of mouse cell lines. J. Biol. Chem. 252:4584-4590.

34. Steinberg, T. H., A. S. Newman, J. A. Swanson, and S. C. Silverstein. 1987. ATP $^{4-}$ permeabilizes the plasma membrane of mouse macrophages to fluorescent dyes. J. Biol. Chem. 262:88848888.

35. Steinberg, T. H., and S. C. Silverstein. 1987. Extracellular $\mathrm{ATP}^{4-}$ promotes cation fluxes in the $\mathrm{J} 774$ mouse macrophage cell line. J. Biol. Chem. 262:3118-3122.

36. Ward, P. A., T. W. Cunningham, K. K. McCulloch, S. H. Phan, J. Powell, and K. J. Johnson. 1988. Platelet enhancement of $\mathrm{O}_{2}^{-}$responses in stimulated human neutrophils. Lab. Invest. 58:37-47.

37. Olsson, I. L., T. R. Breitman, and R. C. Gallo. 1982. Priming of human myeloid leukemic cell lines HL-60 and U-937 with retinoic acid for differentiation effects of cyclic adenosine $3^{\prime}-5^{\prime}$-monophosphate-inducing agents and a T-lymphocyte-derived differentiation factor. Cancer Res. 42:3928-3933. 